Acta Horticulturae et Regiotecturae 1

Nitra, Slovaca Universitas Agriculturae Nitriae, 2017, pp. 6-10

\title{
CONTENT OF SELECTED BIOACTIVE SUBSTANCES IN DEPENDENCE ON LIGHTING IN MICROGREENS
}

\author{
Alena ANDREJIOVÁ*, Alžbeta HEGEDÜSOVÁ, Ivana MEZEYOVÁ, Elka KÓŇOVÁ \\ Slovak University of Agriculture in Nitra, Slovak Republic
}

\begin{abstract}
Young plants, also called "microgreens", are different kinds of vegetables, grains and herbs grown to the phenological phase of cotyledons, or to the development of the first pair of true leaves. The aim of the work was to study the influence of lighting on the young plants quality in selected 11 vegetables species. The experiment was carried out during the winter time in a heated greenhouse of the Botanical Gardens of SUA in Nitra. For the lighting there were used linear fluorescent lamps FLUORA T8 - L 36W / 77 - G13 during the whole period of cultivation. According to our results, the lighting had a positive impact on the quality of harvested plants. The higher contents of vitamin C, chlorophyll $a$ and chlorophyll $b$ were estimated in comparison with the control variant without lighting.
\end{abstract}

Keywords: microgreens, lighting, chlorophyll, vitamin C

Microgreens have gained popularity as a new culinary trend appearing in upscale markets and restaurants over the past few years. Microgreens, frequently called 'vegetable confetti', are defined as tender immature greens produced from the seeds of vegetables, herbs, or grains, including wild species (Lester et al., 2010; Xiao et al., 2012). Depending on species and growing conditions, microgreens are generally harvested at the soil level, i.e. at the base of hypocotyls, upon appearance of the first pair of true leaves, when cotyledons are fully expanded and still turgid, usually within 7-21 days from seed germination depending on the species (Sun et al., 2013). They are tender, cotyledonary-leaf plants having vivid colours, intense flavours and tender textures; therefore, they are usually served fresh as ingredients in salad, soups and sandwiches or used as an edible garnish (Treadwell et al., 2010). Microgreens may be distributed as fresh-cut products but also while growing on media, to be harvested by end users. Mostly exploited are species belonging to the families Brassicaceae, Asteraceae, Chenopodiaceae, Lamiaceae, Apiaceae, Amarillydaceae, Amaranthceae and Cucurbitaceae. Bioactive content is prominent in species of rather acrid taste (e.g. Brassicaceae), the variable acceptability of which warrants identification of genotypes that may cater to demands for both taste and health (Xiao et al., 2015). In a recent study, we found out that microgreens generally contain higher concentrations of phytonutrients (such as $\alpha$-tocopherol, $\beta$-carotene and ascorbic acid) than their mature-leaf counterparts (Xiao et al., 2012). Nutritional composition primarily depends on the growing crop, but also on the growing conditions. Young plants have a significantly higher content of vitamins, compared with adult plants. Due to a higher levels of phytochemical compounds found in these early shoots, these plants are considered to belong to a group known as "functional foods" (Sharma et al., 2012). Selection of genetic material must valorise indigenous resources, such as landraces, underutilized crops and wild edible plants, and quest for a balance between phytonutrient content and organoleptic appeal, as bioactive value tends to run counter to consumer preference for less bitter taste (Kyriacou et al., 2016). Light conditions are highly influential on the morphophysiology of microgreens, and the biosynthesis and accumulation of phytochemicals, especially in controlled growth environments (Delian et al., 2015). Optimal management of light intensity may enhance photosynthetic activity and phytochemical content in vegetables, where an excessive irradiance can provoke photo-damage with detrimental effects on plant growth and product quality (Bian et al., 2015). The advantage of microgreens growing compared with sprouts is a low risk of the micro-organisms development (Treadwell et al., 2010). Young plants lose quality after harvest very quickly and therefore immediate packaging and refrigeration is important (Lee and Lee, 2012).

The aim of our research was to study the effect of lighting on the quality of selected vegetable microgreens grown in a heated greenhouse during winter.

\section{Material and methods}

\section{Trial organization}

The trial was established in a heated greenhouse in the Botanical garden of SUA in Nitra. There were included 11 species of plants suitable for microgreens production (tab. 1). 
Table 1

Observed varieties of selected plant species

\begin{tabular}{|l||c|c|}
\hline \multicolumn{1}{|l||}{ Family } & Species & Variety \\
\hline \hline Amaranthaceae & Amaranth (Amarantuhus tricolor) & 'Geenleafvegetable' \\
\hline \multicolumn{1}{|l||}{ Apiaceae } & Carrot (Daucus carota) & 'Calabrese' \\
\hline \multicolumn{1}{|c|}{ Brassicaceae } & Broccoli (Brassica oleracea var. botrytis italica) & 'Retek' \\
\hline & Radish (Raphanus sativus) & 'Dánská' \\
\hline & Wild rocket (Diplotaxis tenuifolia) & 'Redgiant' (red leaf variety) \\
\hline Chenopodiaceae & Chinese mustard (Brassica juncea) & 'Komatsuna'(green leaf variety) \\
\hline Fabaceae & 'Patrik' \\
\hline Lamiaceae & Garden pea (Pisum sativum) & 'Gloriosa' \\
\hline
\end{tabular}

There were observed two variants in the experiment: the control variant (cultivation without lighting) and the variant with illuminated plants. All monitored species were sown in January 20,2015, in two seeding trays by sowing in rows, in an effort to avoid crop crowding and to prevent the development of pathogens. For sowing, there was used a complex sowing substrate on the base of peat, $\mathrm{pH}$ of substrate was 5.5-6.5. The average temperature for plants growing in the greenhouse was $22^{\circ} \mathrm{C}$. For lighting of the plants there were used linear fluorescent tubes FLUORA T8 $\mathrm{L} 36 \mathrm{~W} / 77$, which were placed at the height of $40 \mathrm{~cm}$ above the plants. The lighting intensity of plants in the greenhouse was determined by luxmeters Testo 545; while without lamps use it was on the level of $1200 \mathrm{~lx}$, with the fluorescent lighting it was $1600 \mathrm{~lx}$ on average. The plants were irrigated twice a day as needed. Harvest of the plants was realised by cutting with scissors in the phenological phase of cotyledons. Microgreens were harvested continually in dependence on the observed species in the term from January 26, 2015, to February 19,2015 . Both variants in the frame of species were harvested at the same time.

\section{Used methods and measurements}

After harvesting of the plants the selected qualitative parameters (chlorophyll $a$, chlorophyll $b$ and vitamin C) were determined in the laboratory of the Department of Vegetable Production (Horticulture and Landscape Engineering Faculty).

\section{The content of vitamin C estimation}

The vitamin C (ascorbic acid) content was determined by a conventional titration method, where the titrant agent was 2.6 dichlorophenol indophenol solutions. Microgreens weighed samples were stabilized by trichloroacetic acid for two hours, then filtered. The assay was carried in an acidic medium and titrated to a pink colour of the solution. The vitamin $\mathrm{C}$ content was calculated according to the chosen methodology.

\section{Determination of chlorophyll $\boldsymbol{a}$ and chlorophyll $\boldsymbol{b}$}

Chlorophyll $a$ and chlorophyll $b$ were determined spectrophotometrically (Spektralquant PHARO 200) laterally in the acetone extract on the wavelengths $\lambda=649 \mathrm{~nm}$ a $\lambda=$ $665 \mathrm{~nm}$ (Hegedűsová et al., 2015). Fresh garden pea seeds (150-200 g) were homogenised and $1 \mathrm{~g}$ of sample weight was wiped in a mortar with sea sand by the addition of 3-4 $\mathrm{ml}$ of acetone. After perfect homogenisation, the acetone extract was filtered through the glass filter S4 device according to Morton. The extraction was repeated until the acetone stayed discoloured. Clear filtrate was decanted into a volumetric flask and it was filled up with $80 \%$ acetone to $50 \mathrm{ml}$. By the help of the measured absorbance values chlorophyll $a$ and chlorophyll $b$ were calculated.

The obtained data were processed into tables in Microsoft Office Excel 2007. Then, analyses of variance (ANOVA) were used by the help of the Tukey test (significance level $\alpha=0.05$ ) for statistical analyses in the program StatgraphicCenturion XVII (StatPointInc. USA).

\section{Results and discussion}

Vitamins and chlorophyll content in microgreens can be improved by cultivation practices, temperature and lighting (Sakalauskienè et al., 2014). It is necessary to select the optimal irradiance level from both agronomic and economic perspective. A minimum level of irradiance is necessary for sufficient synthesis and activity of photosynthetic pigments, biomass, leaf area formation or nitrogen investment between photosynthetic components (Evans and Poorter, 2001; Ilieva et al., 2010). Photoperiod can affect phytochemical accumulation in microgreens, and potentially interact with light quality and intensity (Kyriacou et al., 2016).

\section{Vitamin C content}

In table 2, the level of vitamin $\mathrm{C}$ in fresh mass of microgreens is ranged. According to several authors, the vitamin $C$ content in vegetables depends not only on cultivated species and varieties, but it is also largely affected by the cultivation, nutrition and fertilisation, as well as by the harvest technologies and then by post-harvest treatment and storage (Valšíková et al., 2013; Andrejiová et al., 2014). 
Based on the obtained results, it can be concluded that the vitamin C content was affected mainly by the genotype and between the observed species the significant differences in vitamin $\mathrm{C}$ content were found. They ranged in the control variant in the interval from 4.34 to $57.29 \mathrm{mg} 100 \mathrm{~g} \mathrm{~g}^{-1}$ of fresh matter. Values of vitamin C content in microgreens from our trial were significantly lower than the values indicated by Kopec (2010) in consumed parts of grown vegetables.

Results of the authors Xiao et al. (2012) showed that different microgreens (25 commercially available microgreens) contained extremely varying amounts of vitamins and carotenoids. Total ascorbic acid contents ranged from 20.4 to147.0 $\mathrm{mg}$ per $100 \mathrm{~g}$ fresh weight (FW). In comparison with nutritional concentrations in mature leaves (USDA National Nutrient Database), the microgreen cotyledon leaves possessed higher nutritional densities.

The lighting had positive impact on the vitamin C content of all evaluated plant species and there was statistically highly significant difference in vitamin $C$ content in the

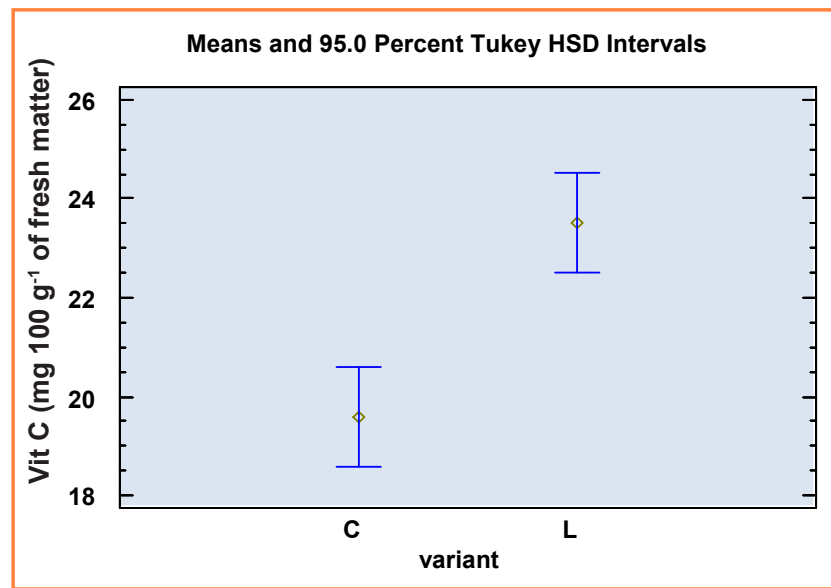

Figure 1 Graphical representation of statistical analysis of vitamin C content in evaluated microgreens depending on the observed variant*

*variant: C - control; L - lighting

Table 2 Vitamin $C$ content in evaluated microgreens* (mg $100 \mathrm{~g}^{-1}$ of fresh matter)

\begin{tabular}{|l||c|c|}
\hline \multicolumn{1}{|l||}{ Species } & \multicolumn{2}{c|}{ Variant } \\
\cline { 2 - 3 } & $12.50 \pm 1.67$ & $16.67 \pm 2.66$ \\
\hline \hline Radish & $12.50 \pm 3.02$ & $16.67 \pm 0.81$ \\
\hline Green mustard & $57.29 \pm 4.22$ & $\mathbf{5 9 . 3 8} \pm \mathbf{3 . 0 8}$ \\
\hline Broccoli & $5.21 \pm 0.89$ & $6.51 \pm 0.02$ \\
\hline Red mustard & $7.81 \pm 1.23$ & $12.50 \pm 1.17$ \\
\hline Wild rocket & $29.17 \pm 3.30$ & $39.38 \pm 3.44$ \\
\hline Garden pea & $\mathrm{x}$ & $\mathrm{x}$ \\
\hline Geetroot & $17.05 \pm 2.78$ & $18.75 \pm 1.82$ \\
\hline Cress & $37.50 \pm 3.25$ & $41.67 \pm 1.92$ \\
\hline Carrot & $12.50 \pm 1.12$ & $18.75 \pm 1.33$ \\
\hline Amaranth & $4.34 \pm 0.70$ & $5.00 \pm 0.08$ \\
\hline Basil & ${ }^{2}$ average \pm standard deviation; $\mathrm{x}-\mathrm{impossible} \mathrm{to} \mathrm{detect}$ \\
\hline
\end{tabular}

monitored variants (Fig. 1). The highest content of vitamin $C$ was established in lighted broccoli $\left(59.38 \mathrm{mg} 100 \mathrm{~g}^{-1}\right.$ of fresh matter). Vitamin C content in beetroot could not be determined because of the anthocyanins in cotyledons, which coloured the sample for titration in cyclamen and it was not possible to make titration with pink colour as an indicator.

\section{Chlorophyll $a$ and $b$ content}

On the basis of the obtained and statistically evaluated data there can be concluded that the impact of lighting significantly contributes to the formation of chlorophyll in plants (Tab. 3-4, Fig. 2-3). When comparing the different variants, increased content of chlorophyll was detected for each kind of species in case of illuminated variant and in some cases it reached almost double value in comparison with the control. Among the observed variants there

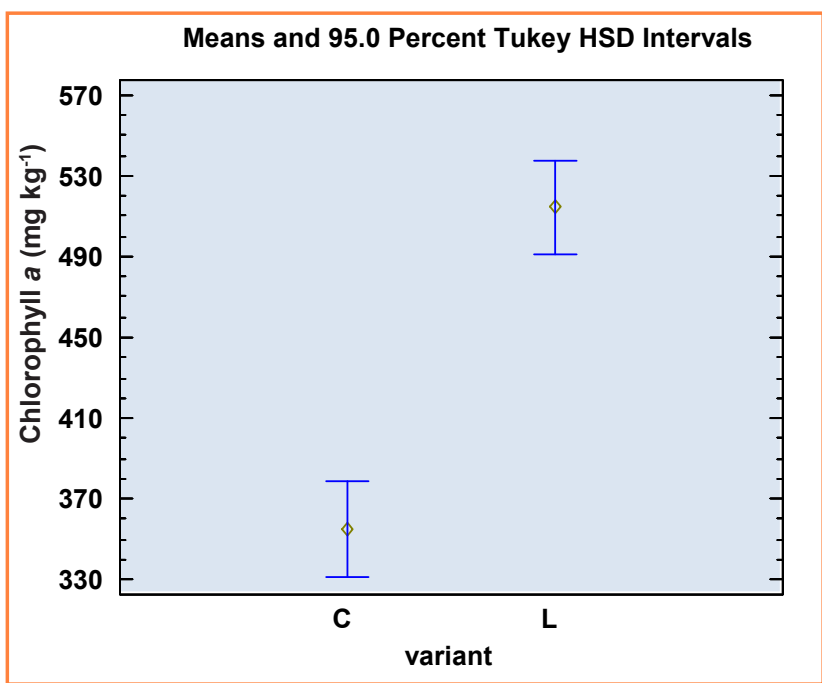

Figure 2 Graphical representation of statistical analyses of chlorophyll $a$ content in evaluated plant species in dependence on observed variant* *variant: C - control; L - lighting

Table 3 Chlorophyll $a$ content * $\left(\mathrm{mg} \mathrm{kg}^{-1}\right.$ of fresh matter)

\begin{tabular}{|c|c|c|}
\hline \multirow[t]{2}{*}{ Species } & \multicolumn{2}{|c|}{ Variant } \\
\hline & Control & Lighting \\
\hline Radish & $325.23 \pm 13.12$ & $465.91 \pm 89.95$ \\
\hline Green mustard & $231.67 \pm 32.14$ & $412.28 \pm 17.07$ \\
\hline Broccoli & $314.75 \pm 28.93$ & $525.50 \pm 55.20$ \\
\hline Red mustard & $241.64 \pm 9.89$ & $409.38 \pm 23.12$ \\
\hline Wild rocket & $276.88 \pm 11.43$ & $523.26 \pm 35,85$ \\
\hline Garden pea & $361.31 \pm 12.49$ & $578.09 \pm 51.16$ \\
\hline Beetroot & $291.87 \pm 23.02$ & $475.97 \pm 24.32$ \\
\hline Cress & $394.41 \pm 37.66$ & $612.08 \pm 49.39$ \\
\hline Carrot & $685.43 \pm 49.11$ & $783.88 \pm 53.17$ \\
\hline Amaranth & $421.42 \pm 31.78$ & $434.64 \pm 18.66$ \\
\hline Basil & $356.06 \pm 27.97$ & $436.36 \pm 21.26$ \\
\hline
\end{tabular}




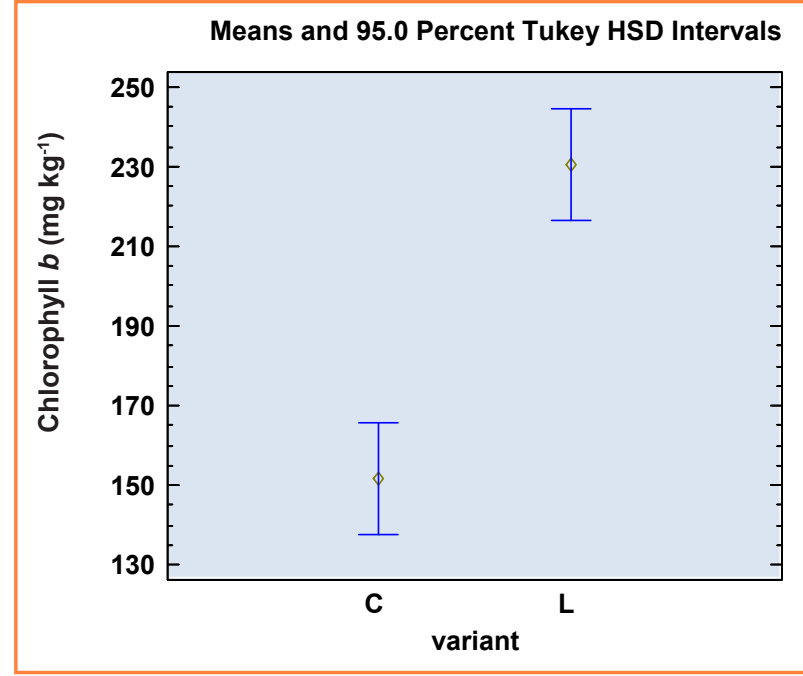

Figure 3 Graphical representation of statistical analyses of chlorophyll $b$ content in evaluated plant species in dependence on observed variant* *variant: C - control; L - lighting

Table $4 \quad$ Chlorophyll $b$ content ${ }^{*}\left(\mathrm{mg} \mathrm{kg}^{-1}\right.$ of fresh matter)

\begin{tabular}{|l||c|c|}
\hline \multicolumn{1}{|l||}{ Species } & \multicolumn{2}{c|}{ Variant } \\
\cline { 2 - 3 } & $139.06 \pm 12.02$ & $198.35 \pm 5.37$ \\
\hline \hline Radish & $100.70 \pm 3.32$ & $176.51 \pm 6.12$ \\
\hline Green mustard & $143.72 \pm 2.14$ & $244.21 \pm 13.66$ \\
\hline Red mustard & $109.60 \pm 0.58$ & $210.17 \pm 4.69$ \\
\hline Wild rocket & $137.72 \pm 1.13$ & $290.92 \pm 4.78$ \\
\hline Garden pea & $123.00 \pm 4.78$ & $228.42 \pm 11.79$ \\
\hline Beetroot & $104.39 \pm 9.27$ & $178.64 \pm 9.96$ \\
\hline Cress & $171.30 \pm 14.69$ & $285.68 \pm 14.12$ \\
\hline Carrot & $317.79 \pm 23.65$ & $352.07 \pm 19.76$ \\
\hline Amaranth & $155.30 \pm 12.12$ & $164.65 \pm 6.02$ \\
\hline Basil & $167.24 \pm 17.01$ & $205.79 \pm 14.78$ \\
\hline
\end{tabular}

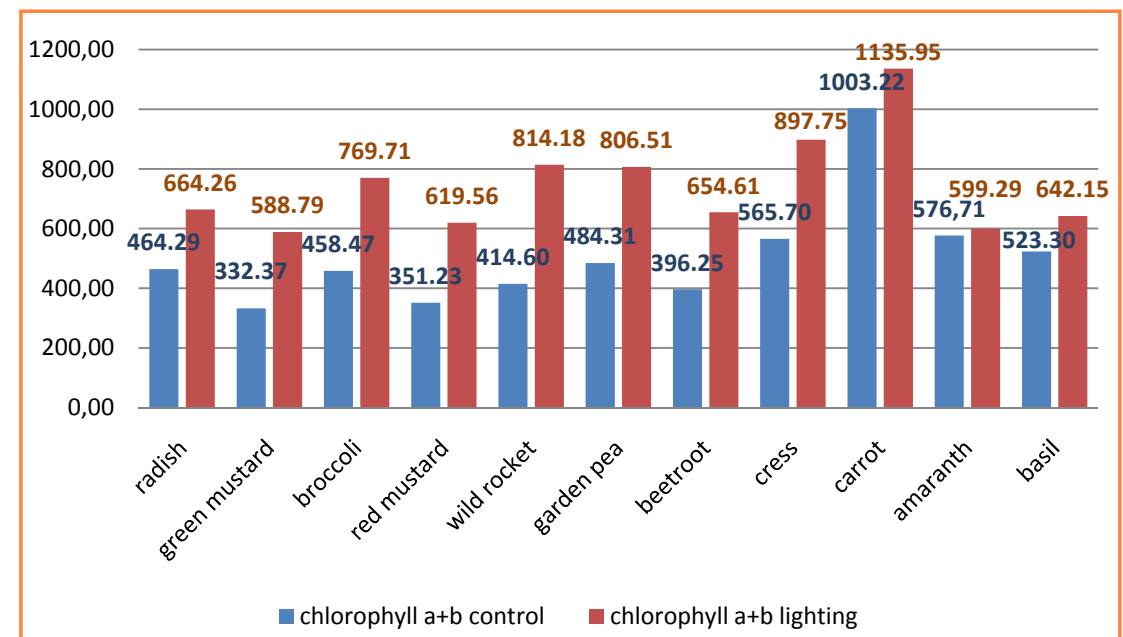

Figure 4 Total chlorophyll $(a+b)$ content $\left(\mathrm{mg} \mathrm{kg}^{-1} \mathrm{mg} 100 \mathrm{~g}^{-1}\right.$ of fresh matter)

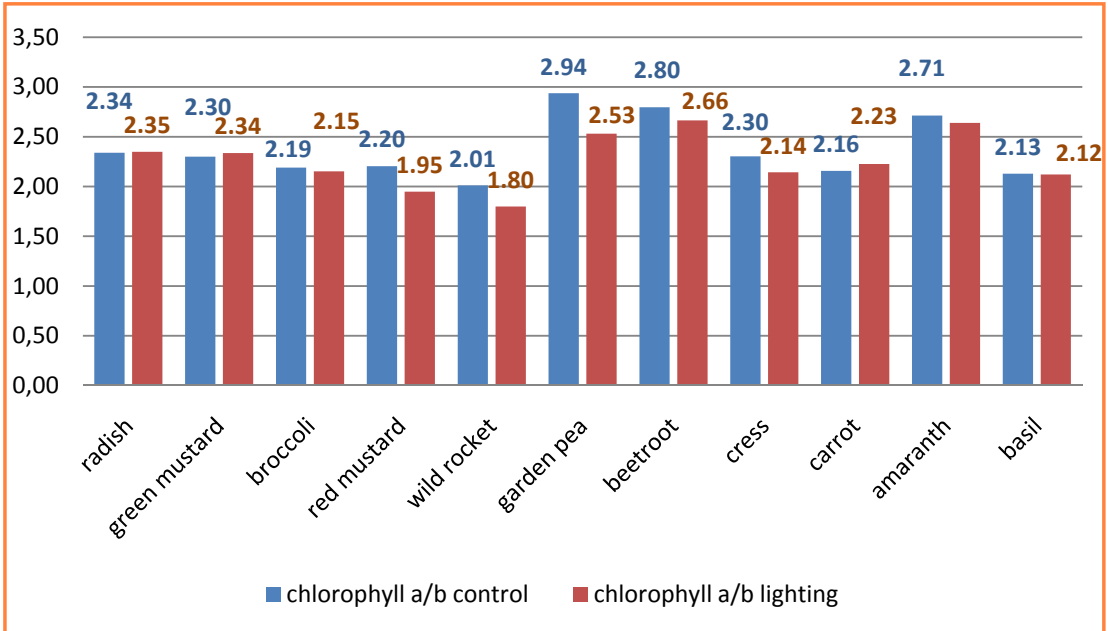

Figure 5 Ratio of evaluated pigments (chlorophyll $a$ / chlorophyll $b$ ) was found a statistically significant difference in chlorophyll $a$ content in monitored species.

The content of total chlorophyll $(a+b)$ in microgreens in case of all observed species was increased under the lighting influence (Fig. 4).

Certain ratio of pigments is typical for fully functional green tissues. Deceleration or blocking of the chlorophyll production causes increase of the chlorophyll a / chlorophyll $b$ ratio. Stress and aging of tissues decrease the chlorophyll content and the ratio of chlorophyll $a$ / chlorophyll $b$ reaches a value of 3 . Finally, it leads to the decomposition of the chlorophyll (Hegedűsová et al., 2015).

From the pigment ratio counted in our trial in the monitored species, there can be concluded that since the microgreens are yours plants, the ratio of the chlorophyll was low, lower than 3 (Fig. 4). Under the influence of the lighting, insignificant changes of the both chlorophylls ratio was noticed in comparison with the control.

\section{Conclusion}

In the submitted work, the results of microgreens growing of selected vegetables in a heated greenhouse are presented. Intensity of illumination significantly influences the quality of growing microgreens during the winter time. Under unfavourable growing conditions there starts lifting of the crops, followed by plant 
lying as well as partial etiolation. Influence of lighting on qualitative parameters (vitamin $C$, chlorophyll $a$ and $b$, total chlorophyll content and the ratio of monitored pigments) was evaluated in a trial. Significantly positive impact of lighting during the microgreens growing was detected on the quality improvement of harvested plants, which resulted in the increases of vitamin C and chlorophyll content in the tested plants species. In term of a growing season, there is recommendation of Brassicaceae species cultivating during the winter time, because they require a very short period for microgreens growing.

\section{Acknowledgement}

The work was supported by VEGA project No. 1/0105/14 and KEGA project 038SPU-4/2014.

\section{References}

ANDREJIOVÁ, A. - BARÁTOVÁ, S. - ŠLOSÁR, M. 2014. Kyselina listová vo vybraných druhoch zeleniny. In Nové smery vo výžive a v životnom štýle ludí. Nitra : UKF, 2014. pp. 149-170. 978-80-558-0629-7

BIAN, Z. H. - YANG, Q. C. - LIU, W. K. 2015. Effects of light quality on the accumulation of phytochemicals in vegetables produced in controlled environments: a review. In Journal wof the Science of Food and Agriculture, vol. 95, pp. 869-877. DOI: 10.1002/jsfa.6789. DELIAN, E. - CHIRA, A. - BADULESCU, L. - CHIRA, L. 2015. Insight into microgreens physiology. In Scientific papers, Series B, Horticulture, vol. 59, pp. 447-454. ISSN 2286-1580.

EVANS, J.R. - POORTER, H. 2001. Photosynthetic acclimation of plants to growth irradiance: the relative importance of specific leaf area and nitrogen partitioning in maximizing carbon gain. In Plant, Cell \& Environment, vol. 24, no. 8, pp. 755-767. doi: 10.1046/j.1365-3040.2001.00724.x

HEGEDÜS, O. - HEGEDÜSOVÁ, A. - ŠIMKOVÁ, S. 2007. Selén ako biogénny prvok. Vedecká monografia. Nitra: UKF, 2007, 76 p. ISBN 978-80-8094-168-0.

HEGEDÜSOVÁ, A. - MEZEYOVÁ, I. - ANDREJIOVÁ, A. 2015. Metódy stanovenia vybraných biologicky aktívnych látok. Nitra : SPU, 2015, 75 p. ISBN 978-80-552-1420-7.

HEGEDÜSOVÁ, A. - MEZEYOVÁ, I. - HEGEDÜS, O. - MUSILOVÁ, J. - PAULEN, O. 2015. Selenium content increasing in the seeds of garden pea after foliar biofortification. In Potravinarstvo, vol. 9, 2015, no. 1, pp. 435-441. doi:10.5219/559

ILIEVA I. - IVANOVA, T. - NAYDENOV, Y. - DANDOLOV, I. - STEFANOV, D. 2010. Plant experiments with light-emitting diode module in Svet space greenhouse. In Advances in Space Research, vol. 46, 2010, no. 7, pp. 840-845. Available at: http://dx.doi.org/10.1016/j. asr.2010.05.009
KOPEC, K. 2010. Zelenina ve vyživě člověka. Praha: Grada Publishing, 2010, 168 p. ISBN 978-80-247-2845-2

KYRIACOU, M. C. - ROUPHAEL, Y. - DI GIOIA, F. - KYRATZIS, A. SERIO, F. - RENNA, M. - DE PASCALE, S. - SANTAMARIA, P. 2016. Micro-scale vegetable production and the rise of microgreens. In Trends in Food Science \& Technolog, vol. 57, 2016, pp. 103-115.

LEE, J. - LEE, Y. 2012. Effect of Packaging Methods on Postharvest Quality of Tah Tasai Chinese Cabbage (Brassica campestris var. narinosa) Baby Leaf Vegetable. In Korean Journal of Food Preservation, vol. 19, 2012, no. 1, pp. 1-6. ISSN 2287-7428.

LESTER, G. E. - MAKUS, D. J. - HODGES, D. M. 2010. Relationship between fresh packaged spinach leaves exposed to continuous light or dark and bioactive contents: Effects of cultivar, leaf size, and storage duration. In Journal of Agricultural and Food Chemistry, vol. 58, 2010, no. 5, pp. 2980-2987. doi: 10.1021/jf903596v

SAKALAUSKIENĖ, S. - BRAZAITYTĖ, A. - VIRŠILĖ, A. - JANKAUSKIENE், J. - SAMUOLIENĖ, G. - SIRTAUTAS, R. - NOVIČKOVAS, A. -VAŠTAKAITĖ, V. - MILIAUSKIENĖ, J. - DUCHOVSKIS, P. 2014. The effect of shortterm red lighting on brassicaceae microgreens grown indoors. In The $29^{\text {th }}$ International Horticultural Congress. Australia, Brisbane, 2014-08-17, 2383. Available at: http://ihc2014.digitalposter.com. au/

SHARMA, P. - GHIMERAY, AK. - GURUNG, A. - JIN, CW. - RHO, HS. $\mathrm{CHO}, \mathrm{DH} .2012$. Phenolic contents, antioxidant and $\alpha$-glucosidase inhibition properties of Nepalese strain buckwheat vegetables, In African Journal of Biotechnology, vol. 11, 2012, no. 1, pp. 184-190. SUN, J. - XIAO, Z. - LIN, L. - LESTER, G. E. - WANG, Q. - HARNLY, J. M. - CHEN, P. 2013. Profiling Polyphenols in Five Brassica Species Microgreens by UHPLC-PDA-ESI/HRMSn. In Journal of Agricultural and Food Chemistry, no. 61 (46) pp. 10960-10970. doi: 10.1021/ jf401802n.

TREADWELL, D. - HOCHMUTH, R. - LANDRUM, L. - LAUGHLIN, W. 2010. Microgreens: A New Specialty Crop. (p. HS1164). University of Florida, IFAS Extension. [online] [cit. 2016-04-12] Available at: http://edis.ifas.ufl.edu/hs1164

VALŠÍKOVÁ, M. - ŠLOSÁR, M. - RYBAN, R. - SHEHATA, S. HEGEDÜSOVÁ, A. 2013. Changes in Vitamin C Content and Soluble Solids of Carrot Content (Daucus carota L.) During Storage. In Acta Horticulturae et Regiotectuare, vol. 16, 2013, no. 1, pp. 1-3. ISSN (Online) 1338-5259. doi: 10.2478/ahr-2013-0001

XIAO, X. - LESTER, G. E. - LUO, Y. - WANG, Q. 2012. Assessment of vitamin and carotenoid concentrations of emerging food products: edible microgreens In Journal of Agricultural and Food Chemistry, vol. 60 (31), 2012, pp. 7644-7651. doi: 10.1021/jf300459b

XIAO, Z. - LESTER, G. E. - PARK, E. - SAFTNER, R. A. - LUO, Y. - WANG, Q. 2015. Evaluation and correlation of sensory attributes and chemical compositions of emerging fresh produce: Microgreens. In Postharvest Biology and Technology, vol. 110, 2015, pp. 140-148. Available at: http://dx.doi.org/10.1016/j.postharvbio.2015.07.021 